\title{
Biology and Impacts of Pacific Island Invasive Species. 3. The African Big-Headed Ant, Pheidole megacephala (Hymenoptera: Formicidae) ${ }^{1}$
}

\author{
Fames K. Wetterer ${ }^{2}$
}

\begin{abstract}
In the Pacific region, the African big-headed ant, Pheidole megacephala, is now widespread in tropical areas; populations are also found at higher latitudes in Australia, New Zealand, and Japan. On most inhabited tropical islands in the Pacific, P. megacephala is well known as a household and agricultural pest. Because P. megacephala does not attack humans, this species is often not recognized as an important threat. The negative ecological impact of $P$. megacephala, however, may be greater than that of any other invasive ant species. In areas where it occurs at high density, few native invertebrates persist. Loss of invertebrate species that serve key functions in the natural community (e.g., important prey species) may have cascading effects leading to the subsequent loss of additional species. Pheidole megacephala tends to thrive in open, disturbed habitats with weedy vegetation that can support high densities of plant-feeding Hemiptera, which these ants tend for honeydew. Before 1900, P. megacephala was known in the Pacific region only from Aru Island (Indonesia) and Hawai'i. By the 1930s, it was found through much of Pacific Asia, Melanesia, and Polynesia, but it was not collected in Micronesia until 1950. Currently P. megacephala is known from virtually every tropical island group in the Pacific but not from many islands within the groups, particularly uninhabited islands. Quarantine efforts might be successful in keeping P. megacephala off these islands. Because $P$. megacephala does not commonly dominate areas with intact natural vegetation, setting aside relatively undisturbed habitat on inhabited islands may also be effective in protecting native invertebrates from attack by this ant.
\end{abstract}

INVASIVE ANTS ARE spreading throughout the Pacific, moving from island to island, killing off native species. They are ubiquitous, yet they go largely unnoticed, as do the great losses they inflict. Perhaps due to their small size, they are usually not taken very seriously. This is a mistake.

Invasive ants are "tramp" species that associate with humans and are spread by human commerce. They travel the world hidden in our plant products, packaging material, building supplies, and heavy machinery such as logging and military equipment. For the

\footnotetext{
${ }^{1}$ Manuscript accepted 20 November 2006.

${ }^{2}$ Wilkes Honors College, Florida Atlantic University, 5353 Parkside Drive, Jupiter, Florida 33458 (phone: 561799-8648; fax: 561-799-8602; e-mail: wetterer@fau.edu).
}

Pacific Science (2007), vol. 61, no. 4:437-456

(C) 2007 by University of Hawai'i Press

All rights reserved most part, tramp ants thrive only in disturbed environments and do not penetrate intact natural habitats. But as humans and their disturbance spread, so do the tramp ants. $\mathrm{Hu}-$ mans tend to kill off the largest of the native animals. The accompanying ants help eradicate much of what remains. Most of these losses go unappreciated and unrecorded.

More than 35 species of tramp ants have invaded the Pacific (Wilson and Taylor 1967; J.K.W., unpubl. data). The ecological importance of most of these species remains undocumented. Several, however, are known to have dramatic impacts in the Pacific. Perhaps the worst is the African big-headed ant, Pheidole megacephala (Fabricius).

\section{NAME}

Pheidole megacephala (Fabricius, 1793)

Phylum Arthropoda, class Insecta, order Hymenoptera, family Formicidae 
Common names ${ }^{*}$, also a common name for the entire genus Pheidole): big-headed ant* (most widely used name), bigheaded ant* (e.g., Nishida 2001), African big-headed ant (e.g., Hoffmann and O'Connor 2004), brown house ant (used in Africa [e.g., Broekhuysen 1948, Oswald 1991, Zerhusen and Rashid 1992]), coastal brown ant (used in Australia [e.g., Heterick 1997, Chin 1998]), hormiga leona (Spanish [e.g., Castiñeiras et al. 1982, Maza et al. 2000]), hormiga cabezona* (Spanish [e.g., Chacón de Ulloa 2003]), formigacabeçuda* (Portuguese [e.g., Bueno and Campos-Farinha 1998]), formiga-cabeçudaurbana (Portuguese [e.g., Instituto Hórus 2006]), fourmi à grosse tête* (French [e.g., Le Breton 2003; D. Fournier, pers. comm.]), Oo-zu-aka-ari-Zoku* (Japanese [e.g., Onoyama 1976]), Tsuya-oozu-ari (Japanese [e.g., Ogata and Yamane 1998]).

Former common names: Madeira house ant (e.g., Blackburn and Kirby 1880), house ant of Madeira (e.g., Donisthorpe 1915), Haus-ameise Madeiras (German [e.g., Heer 1852, Forel 1895]).

\section{DESCRIPTION AND ACCOUNT OF VARIATION}

Fabricius (1793) described Pheidole megacephala from "Isle de France," the eighteenthcentury name for the island of Mauritius in the Indian Ocean east of Madagascar.

Pheidole megacephala has been recognized as senior synonym of several described forms: Myrmica trinodis Losana, described from Italy; Formica edax Forsskål, from Egypt; Oecophthora perniciosa Gerstäcker, from Mozambique; Oecophthora pusilla Heer, from Madeira; Pheidole janus F. Smith, from Sri Lanka; Myrmica laevigata F. Smith, from Great Britain; Pheidole laevigata Mayr, from Brazil; Myrmica suspiciosa F. Smith, from Aru Island; and Atta testacea F. Smith, from Brazil (Bolton 1995).

In addition to the nominal subspecies, Bolton (1995) listed 10 other subspecies of $P$. megacephala, all described from Africa: P. megacephala costauriensis Santschi, from Ghana; $P$. megacephala duplex Santschi, from Angola; $P$. megacephala ilgi Forel, from Ethiopia; P. megacephala impressifrons Wasmann, from South
Africa; P. megacephala melancholica Santschi, from Ivory Coast; P. megacephala nkomoana Forel, from Zaire; $P$. megacephala rotundata Forel, from Mozambique; P. megacephala scabrior Forel, from Madagascar; P. megacephala speculifrons Stitz, from Tanzania; and P. megacephala talpa Gerstäcker, from Kenya. Wheeler $(1922: 128)$ concluded: "In all probability $P$. megacephala is of Ethiopian or Malagasy origin, as it shows a great development of subspecies and varieties in these two regions and nowhere else." Although there is debate concerning the taxonomic boundaries among $P$. megacephala, its subspecies, and closely related Pheidole in Africa, the identity of P. megacephala on Pacific islands is clear-cut.

Like all other Pheidole species, P. megacephala shows complete dimorphism (distinct minor and major workers and no intermediates), with majors having disproportionately large heads compared with minors (Figures 1-2). Pheidole megacephala workers are brown, often with the head and abdomen somewhat darker than the mesosoma (Figures 1-2). Total body length is $\sim 2 \mathrm{~mm}$ for minors and $\sim 3.5 \mathrm{~mm}$ for majors. For most Pheidole, majors are essential for species identification. In P. megacephala, however, minors easily can be distinguished from all other Pheidole in the Pacific. The postpetiole in minor $P$. megacephala workers is notably longer than broad, has a prominent ventral convexity visible in side view, and is bell-shaped when viewed from above (S. Cover, pers. comm. [see Figure 3]). Major workers have a heart-shaped head that is smooth and shiny on posterior half (Figure 2). In $P$. megacephala, minor workers typically do most of the foraging and majors primarily remain inside the nest.

About 30 native species of Pheidole are known from Oceania, including three widespread species, Pheidole oceanica Mayr, Pheidole sexspinosa Mayr, and Pheidole umbonata Mayr. In addition, two other exotic Pheidole have been introduced to Oceania: Pheidole fervens F. Smith from Asia and Pheidole moerens Wheeler from the West Indies. Santschi (1919) listed another exotic species, Pheidole teneriffana Forel, in Samoa, but in a later list Santschi (1928) did not include this species, which suggests that he dismissed the earlier 


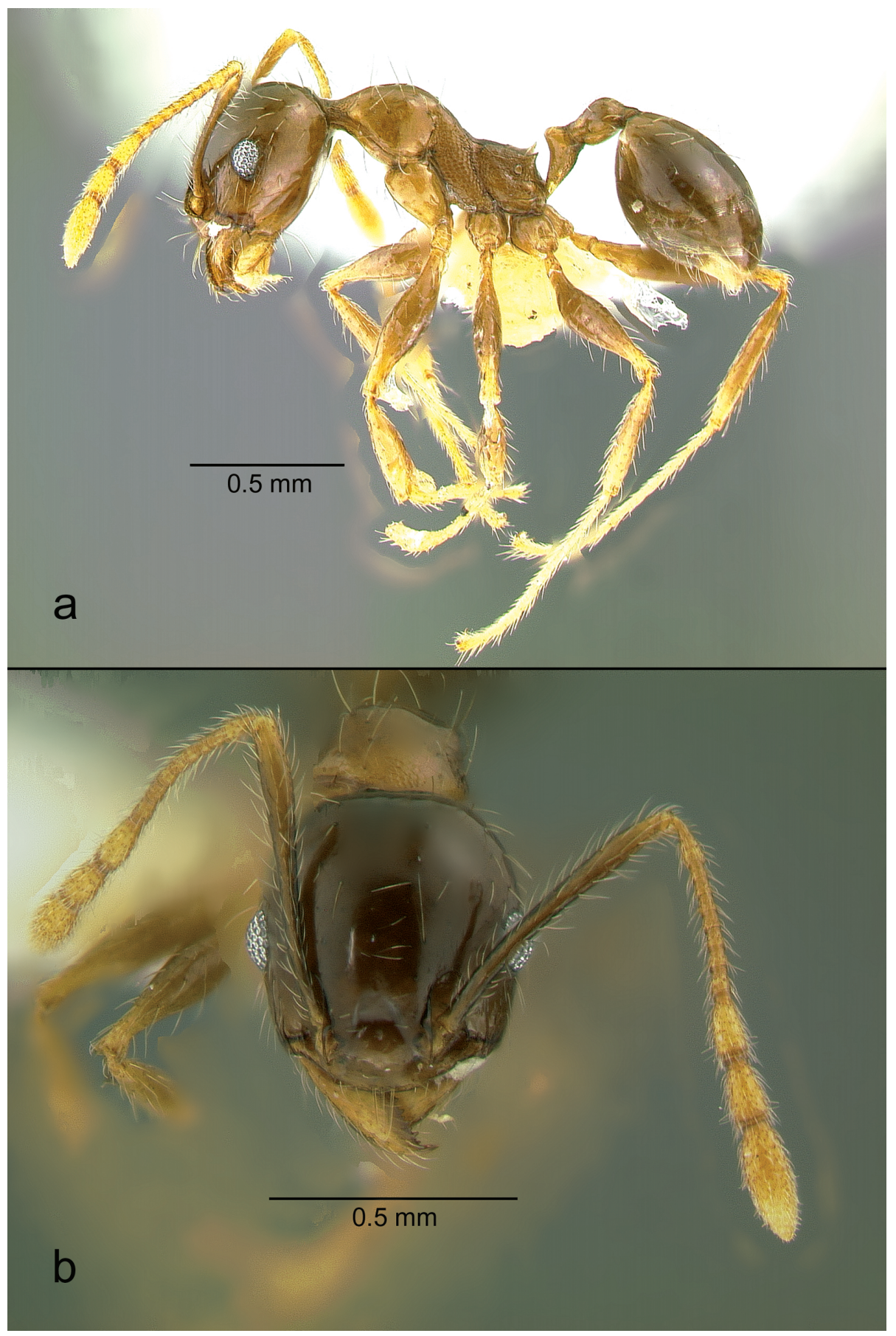

Figure 1. Minor worker of Pheidole megacephala (specimen from Nananu-i-Ra Island, Fiji, July 1997, J. K. Wetterer coll., photos by Gary Alpert). $a$, side view; $b$, head-on view. 


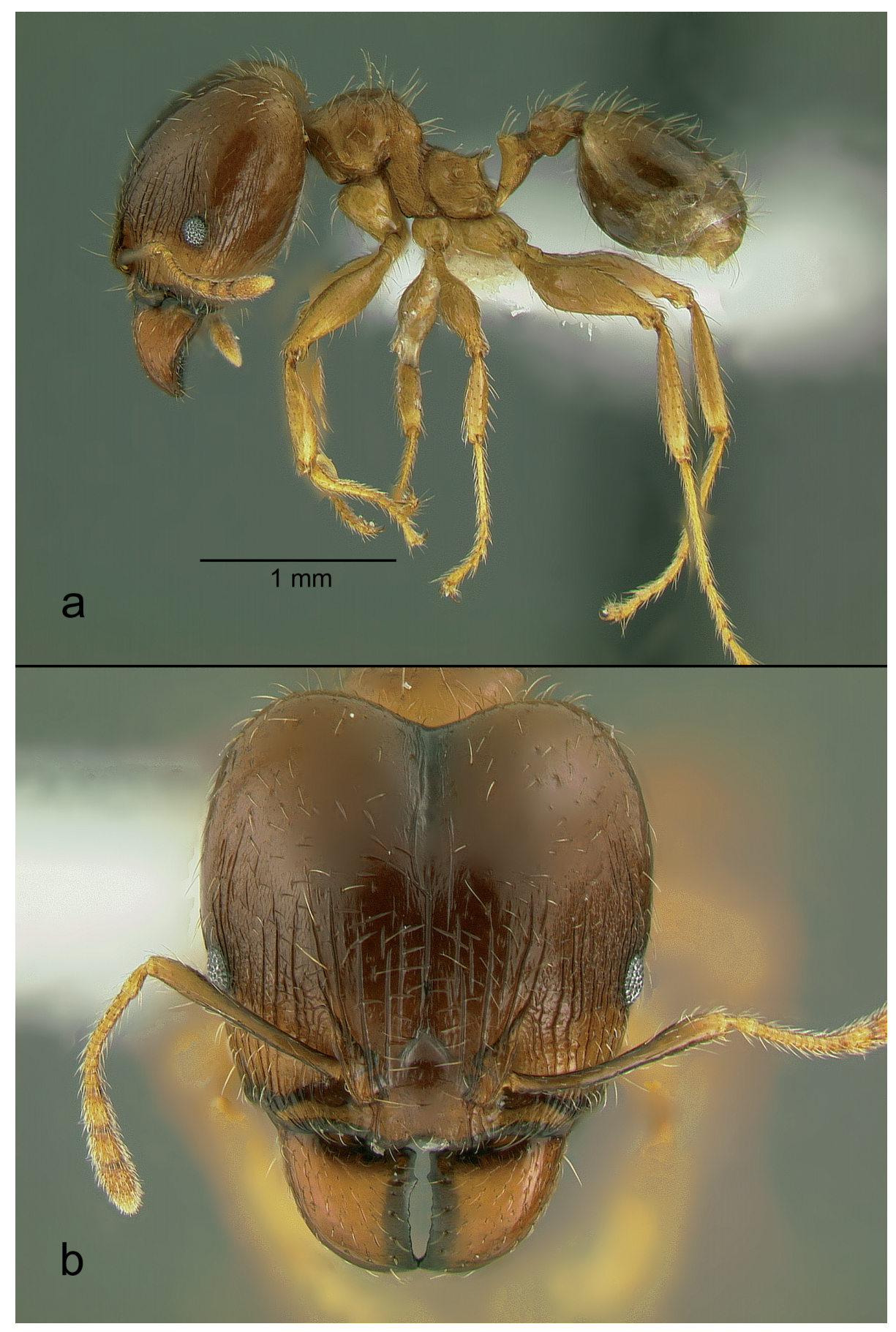

FIgURe 2. Major worker of Pheidole megacephala (same collection and photo data as Figure 1). $a$, side view; $b$, head-on view. 


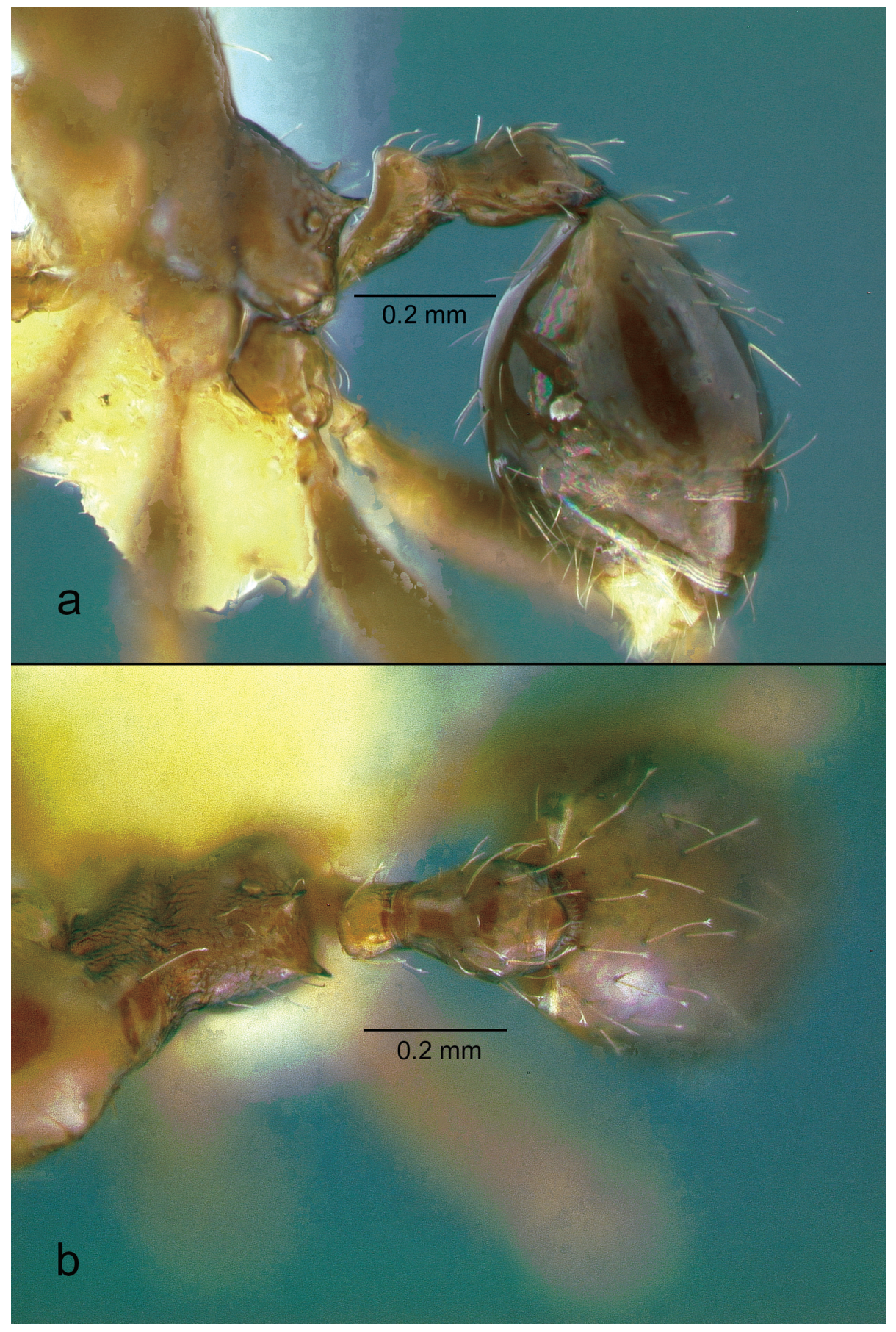

Figure 3. Postpetiole of Pheidole megacephala minor worker (same collection and photo data as Figure 1). $a$, dorsal view; $b$, side view. 
identification. Wilson and Taylor (1967) concluded that the $P$. teneriffana specimens listed by Santschi (1919) were actually $P$. megacephala. Although not yet known from Pacific islands, $P$. teneriffana recently has been collected in Fremantle, Western Australia (B. Heterick, pers. comm.). In Western Australia, $P$. megacephala may be confused with $P$. teneriffana. The postpetiole of $P$. teneriffana minors, however, lacks the prominent ventral convexity present in $P$. megacephala minors. In the majors, the sculpturing on the dorsal surface of the head is confined to the anterior half in $P$. megacephala but covers the entire dorsal surface in P. teneriffana (S. Cover, pers. comm.).

\section{ECONOMIC IMPORTANCE AND} ENVIRONMENTAL IMPACT

\section{Detrimental Aspects}

Pheidole megacephala is well known in the tropical Pacific as both an indoor and outdoor pest. As a household pest, it commonly nests inside buildings and feeds on human foodstuffs (Huddleston and Fluker 1968, Chin 1998). In more temperate areas, P. megacephala may be found nesting exclusively indoors. Pheidole megacephala reportedly attacks and chews through electrical wires, communications cables, and irrigation tubing (Brimblecombe 1958, Chang and Ota 1990).

Pheidole megacephala can be an important agricultural pest on many crops, including pineapple, sugarcane, bananas, coffee, and coconuts, through enhancing populations of the plant-feeding Hemiptera, such as mealybugs, scale insects, and aphids. The ants protect the Hemiptera from predators and parasites while feeding on honeydew that the Hemiptera produce (Fluker et al. 1968, Carver et al. 1987, 1993, Bach 1991, Reimer et al. 1993, Jahn and Beardsley 1994, 1996, González-Hernández et al. 1999a,b). Pheidole megacephala workers will even transport Hemiptera within and among plants (e.g., Wiles et al. 1996). Hemiptera cause crop damage both through sapping plants of nutrients and by increasing the occurrence of diseases, including viral and fungal infections. In the Pacific, $P$. megacephala is particularly noted as a pest of sugarcane and pineapple, through its tending of mealybugs. When $P$. megacephala is eradicated from a pineapple field, populations of mealybugs decline and pineapple wilt disease can be brought under control (Beardsley et al. 1982). Pheidole megacephala tends banana aphids (Stechmann et al. 1996) and increases diseases spread by aphids, such as the banana bunchy top virus. Diseases encouraged by $P$. megacephala tending Hemiptera probably impact native plant communities as well.

Pheidole megacephala has had a great negative impact on native invertebrates in the Pacific (e.g., Gillespie and Reimer 1993, Hoffmann 1998, Hoffmann et al. 1999, LaPolla et al. 2000, Heterick et al. 2000). The impact of $P$. megacephala on native species has been most extensively noted in Hawai'i, though most reports are anecdotal. Like many other remote Pacific islands, the Hawaiian Islands lack an indigenous ant fauna (Wilson and Taylor 1967). When ants invade such islands, they can have devastating effects on the native ecosystems, preying on the relatively defenseless endemic fauna (Zimmerman 1948, Hölldobler and Wilson 1990, Gillespie and Reimer 1993, LaPolla et al. 2000). Perkins (1913:xli) wrote of $P$. megacephala, "It may be said that no native Hawaiian Coleoptera insect can resist this predator, and it is practically useless to attempt to collect where it is well established." Zimmerman (1970:34) wrote that in Hawai' $i$, "the endemic insect faunas of the lowlands of all the islands mostly have been exterminated throughout the range of the voracious introduced predatory ant Pheidole megacephala." Loss of invertebrate species that serve key functions in the natural community (e.g., important prey species, pollinators, seed dispersers, scavengers, decomposers) may have cascading effects leading to severe disruptions of natural nutrient cycling and the subsequent loss of additional native plant and animal species (Howarth 1985).

Pheidole megacephala is extremely aggressive toward other ant species. Colonies of P. mega- 
cephala are strongly territorial and exclude other dominant territorial ants, such as Anoplolepis gracilipes (F. Smith) and Linepithema bumile (Mayr) (Fluker and Beardsley 1970). When live ants are collected in an aspirator, $P$. megacephala workers will quickly cut to pieces other ants in the collection vial (pers. obs.). Pheidole megacephala often dominates over extensive areas (e.g., much of the $\mathrm{Ha}$ waiian lowlands). In many parts of Tonga, I (Wetterer 2002) found P. megacephala under almost every rock and $\log$ and virtually no other ants.

Pheidole megacephala may also negatively impact vertebrates in the Pacific, both directly and indirectly. In Hawai $i$, C. Daehler (pers. comm.) observed (and filmed) hundreds of $P$. megacephala workers attacking 3 -week-old hatchlings of an exotic bird, the Japanese White-eye (Zosterops japonicus). Banko and Banko (1976:31) concluded that in Hawai'i, P. megacephala "played an indirect though paramount role in the reduction and extinction of all insectivorous birds. Pheidole was particularly effective in displacing an exceptionally wide variety of insects, even causing species extinctions in the Coleoptera and Lepidoptera, the two orders of insects which are most important as food to a majority of insectivorous birds of the Hawaiian Islands." Concerning the decline of the Laysan Duck (Anas laysanensis Rothschild), Reynolds et al. (2005) wrote "alien insects, including bigheaded ants (Pheidole megacephala) are suspected of reducing the duck's food abundance."

A great negative impact of $P$. megacephala on native species is not inevitable everywhere. Pheidole megacephala first came to widespread attention as a result of an enormous outbreak in the city of Funchal, on the subtropical Atlantic island of Madeira (Heer 1852). Many authors have long assumed that $P$. megacephala has exterminated most or all of the native ants of Madeira (Wetterer 2006b). However, after 150 or more years of residence on Madeira, P. megacephala has come to occupy only a tiny range and appears to have had little impact (Wetterer et al. 2006). Most of Madeira may be too cool for $P$. megacephala to dominate. Also, Madeira's vast natural areas may generally lack weedy vegetation that can support high densities of plant-feeding Hemiptera critical for the ecological dominance of invasive ants. Finally, a dominant native ant, Lasius grandis Forel, inhabiting $\sim 84 \%$ of Madeira, may actively exclude $P$. megacephala.

\section{Beneficial Aspects}

Because P. megacephala workers are efficient predators on other invertebrates, capable of subduing prey much larger than themselves, P. megacephala is sometimes considered a beneficial biocontrol agent against other insect pests. Illingworth (1927:389) wrote, concerning $P$. megacephala, "this valuable predaceous ant has driven out of Honolulu many noxious insects, even within the last decade." H. W. Simmonds (1958) attributed a great drop in numbers of houseflies in Fiji to $P$. megacephala. Pheidole megacephala preys on pests that attack sugarcane, bananas, and other crops. For example, $P$. megacephala is an important predator of the sugarcane stem borer, Chilo sacchariphagus Bojer (Goebel et al. 1999); the banana weevil, Cosmopolites sordidus (Germar) (Tinzaara et al. 2005); and the southern green stink bug, Nezara viridula (L.) (a pest of macadamia in Hawai'i [Jones et al. 2001]). Pheidole megacephala was observed to prey upon coconut moths in Fiji (Tothill et al. 1930). Pheidole megacephala is also known to attack pest termites (Cornelius and Grace 1996). In Africa, Cushman et al. (1998) found that the presence of $P$. megacephala benefited figs ( $F i$ cus spp.) by reducing seed predators and parasitoids of pollinating fig wasps. Rosset (1996 in World Resources Institute 2000:160) reported that in Cuba, "growers have been releasing predatory ants (Pheidole megacephala) to control the sweet potato weevil (Cylas formicarius), a method that has proven 99 percent effective." Lagnaoui et al. (2000:3) described how to move $P$. megacephala colonies using rolled banana leaves from banana plantations, where they were common, to sweet potato fields; they reported that "setting up colonies in the field 30 days after planting 
with 60-110 nest/ha can keep weevil infestations at low levels (3-5\%)."

\section{GEOGRAPHICAL DISTRIBUTION}

Climate appears to be the most important factor in determining the geographic limits of Pheidole megacephala. In the Pacific, $P$. megacephala is known primarily from tropical lowland regions but ranges into more temperate latitudes in Australia (to $37^{\circ} \mathrm{S}$ [Nikitin 1979]), New Zealand (to $37^{\circ} \mathrm{S}$ [Taylor 1961]), and the Ryukyu Islands of Japan (to $27^{\circ} \mathrm{N}$ [Yamauchi and Ogata 1995]). Within many invaded island groups in the Pacific, $P$. megacephala has a scattered distribution and is not yet present in numerous islands, particularly uninhabited islands (e.g., the northernmost Mariana Islands).

Around the Pacific rim, P. megacephala has been found in Australia (e.g., Forel 1902, 1915, Tryon 1912, Crawley 1915, Clark 1941, Nikitin 1979, Vanderwoude et al. 2000), China (e.g., Wheeler 1927, Zhou and Zheng 1999), Indonesia (e.g., Smith 1871, Emery 1900, Forel 1909, Wheeler 1924), Japan (e.g., Sonobe 1973, Onoyama 1976, Abe and Maeda 1977, Yamauchi and Ogata 1995), Papua New Guinea (e.g., Room 1975), the Philippines (e.g., Forel 1907), Taiwan (e.g., Wheeler 1909, 1929, Forel 1912), and Vietnam (e.g., Karawajew 1935).

In Melanesia, P. megacephala has been collected in Fiji (e.g., Mann 1925, Santschi 1928, Wilson and Taylor 1967), New Caledonia (e.g., Jourdan 1997), Solomon Islands (e.g., Forel 1910, Wheeler 1935, Wilson and Taylor 1967, Greenslade 1971), and Vanuatu (e.g., Chazeau and Bonnet de Larbogne 1999).

In Polynesia, $P$. megacephala has been recorded from the Cook Islands (Taylor 1967, Wilson and Taylor 1967), French Polynesia (e.g., Wheeler 1908, 1932a,b, 1933, 1935, 1936, Cheesman and Crawley 1928, Perrault 1988), Hawai'i (e.g., Smith 1879, Blackburn and Kirby 1880, Forel 1899, Timberlake 1926, Wheeler 1934, Huddleston and Fluker 1968, Gagné 1979, Medeiros et al. 1986, Asquith and Messing 1993, GonzálezHernández et al. 1999a,b, LaPolla et al. 2000, Jones et al. 2001, Nishida 2001, Starr et al. 2004), New Zealand (Taylor 1961, 1971, Green 1992, Berry et al. 1997), Niue (e.g., Taylor 1967, Wetterer 2006a), Samoa (e.g., Santschi 1928, Wetterer and Vargo 2003), Tokelau Islands (e.g., Dale 1959, Hinckley 1969), Tonga (e.g., Dlussky 1994, Stechmann et al. 1996, Wetterer 2002), and Wallis and Futuna (Wilson and Hunt 1967).

In Micronesia, P. megacephala has been recorded from the Federated States of Micronesia (e.g., previously unpublished records in Table 2), Kiribati (e.g., Wilson and Taylor 1967), Mariana Islands (e.g., Schreiner 1991, Wiles et al. 1996), Marshall Islands (e.g., Sugerman 1972), Palau (e.g., Hoffmann 2004), and U.S. Pacific Territories (e.g., Chilson 1959).

Only a few Pacific island groups still lack records of $P$. megacephala (Table 1). For some tropical islands (e.g., Nauru, Tuvalu, Phoenix Islands, Tuamotu Islands, and the Galápagos), this may be due to a lack of collection information. The scarcity of records in all temperate parts of the world suggests that $P$. megacephala may not be able to establish outdoor populations on more-temperate Pacific islands (e.g., Bonin Islands, Pitcairn Island, Easter Island, and Juan Fernández Islands).

\section{HABITAT}

Pheidole megacephala tends to be more common in open, disturbed habitats with weedy vegetation that can support high densities of the plant-feeding Hemiptera that the ants tend for honeydew. Typically, P. megacephala is largely absent in intact natural forest, even in Hawai' $i$, which lacks any native ant competitors (Wetterer 1998). This absence may be due to a general scarcity of plant-feeding Hemiptera in forested areas. In New Caledonia, Jourdan (1997) found a variety of exotic ants, including Paratrechina longicornis (Latreille) and Wasmannia auropunctata (Roger), in intact forest and shrub habitats but found $P$. megacephala only in heavily disturbed "anthropic" areas. In Fiji, Mann (1925:5) noted that "especially in the cultivated districts, it was one of the commonest ants." Wetterer and Vargo (2003) commonly found 
TABLE 1

Presence and Absence of Pheidole megacephala in the Pacific

\begin{tabular}{|c|c|c|c|}
\hline Pacific Locales & Present & Absent & No Data \\
\hline American Samoa & $\mathrm{X}$ & & \\
\hline Australia & $\mathrm{X}$ & & \\
\hline Bonin Islands & & & $\mathrm{X}$ \\
\hline Cocos Islands & & $\mathrm{X}$ & \\
\hline Cook Islands & $X$ & & \\
\hline Easter Island & & $\mathrm{X}$ & \\
\hline Fiji & $\mathrm{X}$ & & \\
\hline French Polynesia & $\mathrm{X}$ & & \\
\hline Galápagos İslands & & $\mathrm{X}$ & \\
\hline Guam & $\mathrm{X}$ & & \\
\hline Hawaiian Islands & $\mathrm{X}$ & & \\
\hline Indonesia & $\mathrm{X}$ & & \\
\hline Japan & $X$ & & \\
\hline Juan Fernández & & $\mathrm{X}$ & \\
\hline Kiribati & $\mathrm{X}$ & & \\
\hline Marshall Islands & $\mathrm{X}$ & & \\
\hline Micronesia & $\mathrm{X}$ & & \\
\hline Nauru & & & $\mathrm{X}$ \\
\hline New Caledonia & $\mathrm{X}$ & & \\
\hline New Zealand & $\mathrm{X}$ & & \\
\hline Niue & $\mathrm{X}$ & & \\
\hline Norfolk Island & & $\mathrm{X}$ & \\
\hline $\begin{array}{l}\text { Northern Mariana } \\
\text { Islands }\end{array}$ & $X$ & & \\
\hline Palau & $X$ & & \\
\hline Papua New Guinea & $\mathrm{X}$ & & \\
\hline Philippines & $\mathrm{X}$ & & \\
\hline Pitcairn Island & & & $\mathrm{X}$ \\
\hline Solomon Islands & $\mathrm{X}$ & & \\
\hline Taiwan & $\mathrm{X}$ & & \\
\hline Tokelau Island & $\mathrm{X}$ & & \\
\hline Tonga & $X$ & & \\
\hline Tuvalu & & & $\mathrm{X}$ \\
\hline Vanuatu & $\mathrm{X}$ & & \\
\hline Wake Island & & $\mathrm{X}$ & \\
\hline Wallis and Futuna & $\mathrm{X}$ & & \\
\hline
\end{tabular}

P. megacephala in disturbed coastal areas but not in relatively undisturbed mountainous areas. In Tonga, Wetterer (2002) found $P$. megacephala in high densities over vast areas in relatively flat, disturbed habitats on the islands of Tongatapu and 'Eua. On Tongatapu, $P$. megacephala also dominated in Toloa Forest Reserve, a flat, relatively intact natural area. The forested eastern slope of 'Eua, too steep for cultivation, however, had not been invaded by $P$. megacephala. In Australia, $P$. megacephala is most often dominant in disturbed areas (e.g., Majer 1985, Heterick
1997, Heterick et al. 2000) but has also invaded some areas of intact forest (Hoffmann et al. 1999, Vanderwoude et al. 2000).

In Hawai' $i$, P. megacephala is common in the lowlands, at elevations up to $900 \mathrm{~m}$ (Perkins 1913, Gagné 1979, Reimer 1994). Medeiros et al. (1986) found $P$. megacephala at elevations up to $1,220 \mathrm{~m}$ on the Big Island and up to $1,250 \mathrm{~m}$ on Maui. Wetterer (1998) found $P$. megacephala in very high densities in and around the geothermal area near the park headquarters in Hawai' $i$ Volcanoes National Park (1,200-1,220 m elevation). The geothermal areas and park buildings appear to serve as warm "habitat islands" that allow $P$. megacephala to extend its ranges to higher elevations. Wetterer et al. (1998) found $P$. megacephala at a disturbed site on Mauna Kea (1,770 m elevation). Reimer et al. (1990) reported that $P$. megacephala is also limited by rainfall and rarely found in very dry $(<38-$ $50 \mathrm{~cm}$ annual rainfall $)$ or wet areas $(>250 \mathrm{~cm}$ annual rainfall). Beardsley et al. (1982) found that periods of heavy rainfall were often followed by a great drop in the numbers of $P$. megacephala in pineapple fields.

\section{HISTORY}

The oldest record of $P$. megacephala from the Indo-Pacific region comes from Aru Island, Indonesia (Smith 1859 [as Myrmica suspiciosa]). The earliest records from Oceania come from Hawai'i (Smith 1879, Blackburn and Kirby 1880, Forel 1899). Banko and Banko (1976) speculated that P. megacephala probably arrived in Hawai'i by 1825 . Over the course of the twentieth century, P. megacephala spread throughout tropical parts of the Pacific region. By the 1930s, it was found through much of Pacific Asia, Melanesia, and Polynesia. In Micronesia, P. megacephala was not collected until 1950, and there were no published reports until 1972 (Table 2).

After its arrival on one island in a group, $P$. megacephala often soon spreads to many nearby islands, particularly inhabited ones. In the Hawaiian Islands, Blackburn and Kirby (1880:89) reported that $P$. megacephala was "one of the commonest ants in Oahu and probably elsewhere." It was subsequently re- 
TABLE 2

Earliest Known Records of Pheidole megacephala in the Pacific Region

\begin{tabular}{|c|c|c|}
\hline Pacific Region & Year & Source $^{a}$ \\
\hline \multicolumn{3}{|l|}{ Pacific rim } \\
\hline Indonesia & $<1859$ & Smith (1859) \\
\hline Singapore & 1879 & F. Smith; BMNH \\
\hline Australia & $<1902$ & Forel (1902) \\
\hline Papua New Guinea & 1907 & R. Bradley and J. H. Burrett; MCZ \\
\hline Philippines & $<1907$ & Forel (1907) \\
\hline China & 1923 & Wheeler (1927) \\
\hline Vietnam & $<1935$ & Karawajew (1935) \\
\hline Japan: Ryukyu Is. & $<1959$ & Sonobe (1973) \\
\hline \multicolumn{3}{|l|}{ Melanesia } \\
\hline Solomon Is. & $<1910$ & Forel (1910) \\
\hline Fiji & 1915 & Mann (1925) \\
\hline Vanuatu & 1929 & L. Cheesman; BMNH \\
\hline New Caledonia & $<1997$ & Jourdan (1997) \\
\hline \multicolumn{3}{|l|}{ Polynesia } \\
\hline Hawai'i & $<1879$ & Smith (1879) \\
\hline Society Is. (France) & 1907 & Wheeler (1908) \\
\hline Cook Is. & 1914 & Wilson and Taylor (1967) \\
\hline Line Is. & 1922 & Wilson and Taylor (1967) \\
\hline Samoa & 1924 & Santschi (1928) \\
\hline Marquesas Is. (France) & 1925 & Cheesman and Crawley (1928) \\
\hline Tonga & 1930 & Wetterer (2002) \\
\hline Austral Is. (France) & 1934 & Wheeler (1936) \\
\hline Gambier Is. (France) & 1934 & Wheeler (1936) \\
\hline Swains I. (U.S.) & 1940 & Wilson and Taylor (1967) \\
\hline New Zealand & 1942 & Berry et al. (1997) \\
\hline Tokelau & $<1959$ & Dale (1959) \\
\hline Wallis and Futuna & 1965 & Wilson and Hunt (1967) \\
\hline Niue & $<1967$ & Taylor (1967) \\
\hline \multicolumn{3}{|l|}{ Micronesia } \\
\hline Fed. States of Micronesia & 1950 & R. J. Goss; MCZ \\
\hline Gilbert Is. & 1956 & E. S. Brown; BMNH \\
\hline Marshall Is. & $<1972$ & Sugerman (1972) \\
\hline Guam & 1985 & D. Nafus; UGM \\
\hline Northern Mariana Is. & 1990 & I. Schreiner; UGM \\
\hline Palau & 2001 & Hoffmann (2004) \\
\hline
\end{tabular}

${ }^{a}$ Previously unpublished specimen records include collector's name and museum source. BMNH, the Natural History Museum in London; MCZ, Museum of Comparative Zoology; UGM, University of Guam Museum.

ported from the inhabited Big Island, Kaua' $\mathrm{i}$, Moloka'i, Maui, and Ni'ihau (Wheeler 1934, Krauss 1944, Beardsley and Tuthill 1959). Forel (1899:118) reported that P. megacephala was found in Hawai' $i$ "on all islands," but this was certainly an exaggeration. A 1923 expedition to the uninhabited northwestern islands of Hawai'i found P. megacephala only on Midway (Bryan 1926). Decades later it was first collected on Laysan (Butler 1961), and only very recently it was reported for the first time from Kure, Pearl and Hermes, French
Frigate Shoals (Nishida 2001), and Kaho'olawe (Starr et al. 2004). Pheidole megacephala still has not been reported from some of the Northwestern Hawaiian Islands, including Necker, Nīhoa, Lisianski, Johnson, and Wake.

Collection records document the spread of $P$. megacephala to the four island groups of Tonga (from north to south: the Niuas, Vava'u, Ha'apai, and Tongatapu). Museum specimens indicate that $P$. megacephala invaded the far north of Tonga by 1930, but 
the ant was not found on the main island of Tongatapu until 1975 (Wetterer 2002). Dlussky (1994) recorded the first $P$. megacephala in Vava'u in 1980. Wetterer (2002) made the first collections of P. megacephala in 'Eua (the second largest island of Tongatapu) and in Ha'apai in 1995.

Among the Pacific islands most recently invaded by $P$. megacephala are Guam, Rota, and Saipan in the Mariana Islands, where the first records for $P$. megacephala date from 1985, 1990, and 2001, respectively (J.K.W. and O. Bourquin, unpubl. data). Schreiner (1991:9) wrote "according to pest control operators $[P$. megacephala $]$ has been present in at least one housing subdivision in northern Guam for a number of years, but it appears to be spreading, having reached the University only in the last year." Pheidole megacephala has not yet been recorded from the northern uninhabited Mariana Islands (Terayama et al. 1994, J.K.W. and O. Bourquin, unpubl. data).

In Palau, Hoffmann (2004) reported that Idechii collected P. megacephala on the Airport road at Airaiin in 2001 and around shipping containers at the port of Koror in 2003.

\section{PHYSIOLOGY}

Temperature has a substantial effect on development and activity of $P$. megacephala workers. Fluker (1969 in Chang 1985) found that at $20-22^{\circ} \mathrm{C} \mathrm{P}$. megacephala minors took 66-78 days to develop to adulthood (19-23 days as an egg, 28-32 days as a larva, and 19-23 days as a pupa). Phillips (1934 in Chang 1985) found that minor workers raised at $24.5-26.7^{\circ} \mathrm{C}$ took an average of 59 days to go from egg to adult (17 days as an egg, 23 days as a larva, and 19 days as a pupa). Finally, Chang (1985) found that $P$. megacephala minor workers raised at $26-27^{\circ} \mathrm{C}$ took $34-38$ days to go from egg to adult (7-10 days as an egg, 16-17 days as a larva, and 7-11 days as a pupa).

Carnegie (1960) found that P. megacephala workers were not active outside the nest at temperatures below $5^{\circ} \mathrm{C}$ and the speed of workers along a foraging trail increased with temperature. Carnegie (1960) found that the greatest number of $P$. megacephala workers were active outside the nest at temperatures of $24-30^{\circ} \mathrm{C}$, and as a result the amount of activity during different parts of the day and night varied at different times of the year.

\section{REPRODUCTION}

Like most other species of dominant invasive ants, exotic populations of $P$. megacephala typically form "unicolonial supercolonies" (i.e., multiple-queen aggregations of interconnected nests that lack colonial boundaries and intraspecific aggression and act as a single cooperative unit [e.g., Hoffmann et al. 1999]). The absence of intraspecific aggression over large areas is thought to be important in allowing these ants to attain high densities and ecological dominance.

New colonies of $P$. megacephala are commonly founded through budding, with one or more fertile queens accompanied by a group of workers splitting off from the main colony (Beardsley et al. 1982). Reimer and González-Hernández (1993), however, found that new colonies may also be founded by single, inseminated queens. Chang (1985) found that individual $P$. megacephala queens laid 97 to 292 eggs in a 31-day period. Worker larvae or adults subsequently ate many eggs. On average only $38 \%$ of laid eggs developed into larvae.

\section{POPULATION DYNAMICS}

For at least $125 \mathrm{yr}$, P. megacephala has maintained its status as the dominant ant in the lowlands of Hawai'i. In some areas, P. megacephala may be virtually the only ant present. For example, at one site in Hawai'i Jones et al. (2001) found that $P$. megacephala made up $96.6 \%$ of the ants collected. In three heavily infested gardens in Perth, Australia, Heterick et al. (2000) found that $99.9 \%$ of the ants collected in pitfall traps $(6,885$ of 6,889$)$ were $P$. megacephala.

The rapid spread and rise to dominance of $P$. megacephala is well illustrated on the main Tongan island of Tongatapu. Although P. megacephala specimens were collected on Tongatapu by Maddison in 1975, contemporary collections from Tongatapu by Litsinger 
(in 1973-1974) and Watt (in 1975-1977) did not include $P$. megacephala, suggesting that $P$. megacephala populations in the 1970 s were limited. By 1995, however, P. megacephala dominated vast areas of Tongatapu, where it occurred in almost every $\log$ and under almost every rock (Wetterer 2002). Pheidole megacephala appears to be in the process of marching across Guam (Schreiner 1991) and spreading to the other Mariana Islands (J.K.W. and O. Bourquin, unpubl. data).

Great outbreaks of $P$. megacephala are often followed by population crashes. The tremendous population explosion of $P$. megacephala on Madeira in the 1850s has long since crashed; Wetterer et al. (2006) estimated that $P$. megacephala now occupies only $\sim 0.6 \%$ of the land area of Madeira. Wheeler (1910:155) described an outbreak of $P$. megacephala on the tiny tropical Caribbean island of Culebrita: "I was astonished to find [Culebrita] completely overrun with $\mathrm{Ph}$. megacephala. This ant was nesting under every stone and $\log$, from the shifting sand of the sea-beach to the walls of the light-house on the highest point of the island. The most careful search failed to reveal the presence of any other species.... It is highly probable that $P h$. megacephala ... had exterminated all the other ants which must have previously inhabited Culebrita." Later surveys of Culebrita, however, found that the P. megacephala populations had greatly diminished (Torres and Snelling 1997). I do not know of any documented cases of great collapses of P. megacephala in the Pacific.

\section{RESPONSE TO MANAGEMENT}

Reimer et al. (1990:45) reported that "bait formulations of hydramethylnon, fenoxycarb, and fluoroaliphatic sulfonamide have significantly reduced or eliminated $P$. megacephala populations in experimental field trials" (also see Chang and Ota 1990, Reimer and Beardsley 1990). Recently, the most commonly recommended chemical control agent for $P$. megacephala appears to be hydramethylnon in the form of Amdro (Ambrands, Atlanta, Georgia) or Maxforce (Bayer Environmental Science, Leverkusen, Germany) (e.g., Zerhu- sen and Rashid 1992, Heterick et al. 2000, Krushelnycky et al. 2005). When applied in bait stations, Amdro can remain effective for 12 weeks; when broadcasted, Amdro breaks down within 1 day in sunlight or in water (Taniguchi et al. 2005). Chemical control of P. megacephala in urban settings most commonly uses bait delivery. In houses and yards, Chin (1998) recommended applying Amdro or chlorpyrifos in granule form directly into the nest or along ant trails. In agriculture, control efforts usually involve broadcast application of Amdro. Taniguchi et al. (2005), however, recommended using bait stations in agriculture because the chemicals remain active longer and have less detrimental environmental impact.

Complete extirpation of an exotic ant from an island has proven to be extremely difficult. Great efforts in the Galápagos appear to have succeeded in exterminating the little fire ant, $W$. auropunctata, from two small islands, Santa Fe and Marchena (Abedrabbo 1994, Causton et al. 2005). Krushelnycky et al. (2005) reported that one application of Amdro on Moku'auia islet off O'ahu successfully eradicated $P$. megacephala. Unfortunately, another pernicious pest ant, Solenopsis geminata (Fabricius), subsequently colonized the islet. Hoffmann and O'Connor (2004) described the complete eradication of $P$. megacephala from Kakadu National Park in Australia using Amdro. Additional research confirming the long-term success of these eradication efforts would be valuable.

\section{NATURAL ENEMIES}

The main natural enemies of $P$. megacephala are other dominant ant species, including Linepithema bumile (Mayr) and Anoplolepis gracilipes (Smith). Where P. megacephala cooccurs with these species, they maintain mutually exclusive territories (Fluker and Beardsley 1970, Jones et al. 2001). Wetterer (1998) found extremely high densities of $P$. megacephala and A. gracilipes occupying mutually exclusive territories in the geothermal area next to the headquarters in Hawai'i Volcanoes National Park. Pheidole megacephala occupied the eastern part of the geothermal 
area (e.g., Sulfur Banks), and A. gracilipes occupied the western part (e.g., Steaming Bluff). In a number of places, L. bumile has come to be preeminent in areas previously dominated by $P$. megacephala, including parts of Hawai'i and Bermuda, and in houses of Madeira (e.g., Fluker and Beardsley 1970, Wetterer and Wetterer 2004, Wetterer et al. 2006). Wilson and Taylor (1967) noted that $P$. megacephala generally does not co-occur with other dominant Pheidole species in the Pacific, such as $P$. fervens and $P$. oceanica.

Although many parasitoids and parasites are known for ants of the genus Pheidole, few have been found that attack $P$. megacephala. One parasitoid of $P$. megacephala is a eucharitid wasp, Orasema fraudulenta (Reichensperger), recorded from Ethiopia and Yemen (Heraty 1994). Social parasites include Pheidole neokobli Wilson, a workerless ant that parasitizes colonies of Pheidole megacephala melancholica in Africa (Wilson 1984).

A variety of vertebrates has been recorded to prey on P. megacephala. Kido et al. (1993) found $P$. megacephala in the diet of an endemic Hawaiian goby fish. Wheeler (1922) recorded $P$. megacephala in the diets of frogs and toads in Africa. F. J. Simmonds (1958) and Wingate (1965) found that P. megacephala was a common prey in the diets of Anolis lizards in Bermuda. It is likely that many insectivorous vertebrates in the Pacific prey on $P$. megacephala.

\section{PROGNOSIS}

Pheidole megacephala is already known from virtually every tropical island group in the $\mathrm{Pa}$ cific. This ant, however, has not yet invaded many isolated, unpopulated islands within these island groups. Spread of P. megacephala to such islands would almost certainly have a catastrophic impact on the native fauna. Quarantine efforts might be successful in keeping $P$. megacephala off these islands. Studies are needed to evaluate whether islands without $P$. megacephala serve as important repositories of native invertebrate species driven extinct elsewhere. Whereas quarantine is unlikely to be successful on heavily trafficked populated islands, setting aside rela- tively undisturbed habitat may be effective in protecting native invertebrates from attack because $P$. megacephala often does not readily invade or dominate intact natural areas.

\section{ACKNOWLEDGMENTS}

I thank Andrea Wetterer, Margaret Wetterer, Stefan Cover, Brian Heterick, Neil Reimer, and Glenn Taniguchi for comments on the manuscript; Edward O. Wilson and Stefan Cover for advice and encouragement; Stefan Cover for identifying all my Pacific ants; Gary Alpert for his excellent photographs of Pheidole megacephala; Florida Atlantic University for financial support.

\section{Literature Cited}

Abe, T., and A. Maeda. 1977. Fauna and density of ants in sugarcane fields of the southern part of Okinawa Island. Pages 75-91 in S. Ikehara, ed. Ecological studies of nature conservation of the Ryukyu Islands III. University of the Ryukyus, Naha, Okinawa.

Abedrabbo, S. 1994. Control of the little fire ant Wasmannia auropunctata on Santa $\mathrm{Fe}$ Island in the Galápagos Islands. Pages 219-227 in D. F. Williams, ed. Exotic ants: Biology, impact, and control of introduced species. Westview Press, Boulder, Colorado.

Asquith, A., and R. H. Messing. 1993. Contemporary Hawaiian insect fauna of a lowland agricultural area on Kaua'i: Implications for local and island-wide fruit fly eradication programs. Pac. Sci. 47:116.

Bach, C. E. 1991. Direct and indirect interactions between ants (Pheidole megacephala), scales (Coccus viridis) and plants (Pluchea indica). Oecologia (Berl.) 87:233-239.

Banko, W. E., and P. C. Banko. 1976. Role of food depletion by foreign organisms in historical decline of Hawaiian forest birds. Pages 29-34 in Proc. 1st Conf. Nat. Sci., Hawai'i Volcanoes National Park, Hawai'i.

Beardsley, J. W., Jr., T. H. Su, F. L. McEwen, and D. Gerling. 1982. Field investigations on the interrelationships of the 
big-headed ant, the gray pineapple mealybug, and pineapple mealybug wilt disease in Hawaii. Proc. Hawaii. Entomol. Soc. 24:51-67.

Beardsley, J. W., and L. D. Tuthill. 1959. Additions to the known insect fauna of Niihau. Proc. Hawaii. Entomol. Soc. 17:56-61.

Berry, J. A., O. R. Green, and S. O. Shattuck. 1997. Species of Pheidole Westwood (Hymenoptera: Formicidae) established in New Zealand. N. Z. J. Zool. 24:25-33.

Blackburn, T., and W. F. Kirby. 1880. Notes on species of aculeate Hymenoptera occurring in the Hawaiian Islands. Entomol. Mon. Mag. 17:85-89.

Bolton, B. 1995. A new general catalogue of the ants of the world. Harvard University Press, Cambridge, Massachusetts.

Brimblecombe, A. R. 1958. Damage by ants to plastic sheathed cables. Queensl. J. Agric. Sci. 15:157-159.

Broekhuysen, G. J. 1948. The brown house ant (Pheidole megacephala F.). Union S. Afr. Dep. Agric., Bull. 266:1-40.

Bryan, E. H., Jr. 1926. Insects of Hawaii, Johnston Island and Wake Island. Bernice P. Bishop Mus. Bull. 31:1-94.

Bueno, O. C., and A. E. C. Campos-Farinha. 1998. Formigas urbanas: Comportamento das espécies que invadem as cidades brasileiras. Vetores Pragas 1 (12): 13-16.

Butler, G. D. 1961. Insects and other arthropods from Laysan Island. Proc. Hawaii. Entomol. Soc. 17:279-387.

Carnegie, A. J. M. 1960. Effects of temperature variations on the activities of the brown house ant, Pheidole megacephala $\mathrm{F}$. race punctulata Mayr (Hymenopt.: Formicidae). J. Entomol. Soc. South. Afr. 23:304-311.

Carver, M., P. J. Hart, and P. W. Wellings. 1993. Aphids (Hemiptera: Aphidae) and associated biota from the Kingdom of Tonga, with respect to biological control. Pan-Pac. Entomol. 69:250-260.

Carver, M., P. A. Inkerman, and N. J. Ashbolt. 1987. Anagyrus saccharicola Timberlake (Hymenoptera: Encyrtidae) and other biota associated with Saccharicoccus sacchari (Cockerell) (Homoptera: Pseudo- coccidae) in Australia. J. Aust. Entomol. Soc. 26:367-368.

Castiñeiras, A., S. Caballero, G. Rego, and M. González. 1982. Effectividad technicoeconomica del empleo de la hormiga leona Pheidole megacephala en el control del tetuan del boniato Cylas formicarius elegantulus. Cienc. Tec. Agric. Prot. Plantas Suppl. 1982:103-109.

Causten, C. E., C. R. Sevilla, and S. D. Porter. 2005. Eradication of the little fire ant, Wasmannia auropunctata (Hymenoptera: Formicidae), from Marchena Island, Galápagos: On the edge of success? Fla. Entomol. 88:159-168.

Chacón de Ulloa, P. 2003. Hormigas urbana. Pages 351-359 in F. Fernández, ed. Introducción a las hormigas de la región Neotropical. Instituto de Investigación de Recursos Biológicos Alexander von Humboldt, Bogotá, Colombia.

Chang, V. C. S. 1985. Colony revival, and notes on rearing and life history of the big-headed ant. Proc. Hawaii. Entomol. Soc. 25:53-58.

Chang, V., and A. K. Ota. 1990. Ant control in Hawaiian drip irrigation systems. Pages 708-715 in R. K. Vander Meer, K. Jaffe, and A. Cedeno, eds. Applied myrmecology: A world perspective. Westview Press, Boulder, Colorado.

Chazeau, J., and L. Bonnet de Larbogne. 1999. The invasion of the little fire ant Wasmannia auropunctata in Vanuatu. Reports, Pacific Commission, IRD Nouméa, New Caledonia.

Cheesman, L. E., and W. C. Crawley. 1928. A contribution towards the insect fauna of French Oceania.-Part III. Formicidae. Ann. Mag. Nat. Hist. (10) 2: 514-525.

Chilson, L. M. 1959. New ant records for Palmyra Island. Proc. Hawaii. Entomol. Soc. 17:18.

Chin, D. 1998. Ants in the household and backyard. Agnote 156:1-6.

Clark, J. 1941. Notes on the Argentine ant and other exotic ants introduced into Australia. Mem. Natl. Mus. Vic. 12:59-70.

Cornelius, M. L., and J. K. Grace. 1996. Effect of two ant species (Hymenoptera: Formicidae) on the foraging and survival 
of the Formosan subterranean termite (Isoptera: Rhinotermitidae). Environ. Entomol. 25:85-89.

Crawley, W. C. 1915. Ants from North and South-West Australia (G. F. Hill, Rowland Turner) and Christmas Island, Straits Settlements-Part II. Ann. Mag. Nat. Hist. (8) 15: 232-239.

Cushman, J. H., S. G. Compton, C. Zachariades, A. B. Ware, R. J. C. Nefdt, and V. K. Rashbrook. 1998. Geographic and taxonomic distribution of a positive interaction: Ant-tended homopterans indirectly benefit figs across southern Africa. Oecologia (Berl.) 116:373-380.

Dale, P. S. 1959. Notes on some insects and other invertebrates collected in the Tokelau Islands. N. Z. Entomol. 2 (4): 18.

Dlussky, G. M. 1994. Zoogeography of southwestern Oceania [in Russian]. Pages 48-93 in Y. G. Puzatchenko, S. I. Golovatch, G. M. Dlussky, K. N. Diakonov, A. A. Zakharov, and G. A. Korganova, eds. Animal population of the islands of southwestern Oceania (ecogeographic studies). Nauka Publishers, Moscow.

Donisthorpe, H. St. J. K. 1915. British ants. Their life-history and classification. 1st ed. William Brendon and Son, Plymouth.

Emery, C. 1900. Formiche raccolte da Elio Modigliani in Sumatra, Engano e Mentawei. Ann. Mus. Civ. Stor. Nat. (2) 20: 661-688.

Fabricius, J. C. 1793. Entomologia systematica emendata et aucta. Secundum classes, ordines, genera, species, adjectis synonimis, locis observationibus, descriptionibus. Tome 2. C. G. Proft, Hafnia.

Fluker, S. S., and J. W. Beardsley. 1970. Sympatric associations of three ants: Iridomyrmex bumilis, Pheidole megacephala, and Anoplolepis longipes in Hawaii. Ann. Entomol. Soc. Am. 63:1290-1296.

Fluker, S. S., E. W. Huddleston, and J. W. Beardsley. 1968. Some effects of the bigheaded ant on populations of the pink sugarcane mealybug. J. Econ. Entomol. 61:474-477.

Forel, A. 1895. Südpalaearctische Ameisen. Mitt. Schweiz. Entomol. Ges. 9:227-234.
Fauna Hawaiiensis 1:116-122.

1902. Fourmis nouvelles d'Australie.

Rev. Suisse Zool. 10:405-548.

1907. Formiciden aus dem Naturhistorischen Museum in Hamburg. II. Teil. Neueingänge seit 1900. Mitt. Naturhist. Mus. Hambg. 24:1-20.

1909. Ameisen aus Java und Krakatau

beobachtet und gesammelt von Herrn Edward Jacobson. Notes Leyden Mus. 31:221-232.

. 1910. Formicides australiens reçus de MM. Froggatt et Rowland Turner. Rev. Suisse Zool. 18:1-94.

- 1912. H. Sauter's FormosaAusbeute. Formicidae (Hym.). Entomol. Mitt. 1:67-81.

- 1915. Results of Dr. E. Mjöberg's Swedish Scientific Expeditions to Australia 1910-13. 2. Ameisen. Ark. Zool. 9:1-119.

Gagné, W. C. 1979. Canopy-associated arthropods in Acacia koa and Metrosideros tree communities along an altitudinal transect on Hawaii Island. Pac. Ins. 21:56-82.

Gillespie, R. G., and N. Reimer. 1993. The effect of alien predatory ants (Hymenoptera: Formicidae) on Hawaiian endemic spiders (Araneae: Tetragnathidae). Pac. Sci. 47:21-33.

Goebel, R., E. Fernandez, J. M. Begue, and C. Alauzet. 1999. Predation by Pheidole megacephala (Fabricius) (Hym.: Formicidae) on eggs of the sugarcane stem borer Chilo sacchariphagus (Bojer) (Lep.: Pyralidae) in Reunion Island. Ann. Soc. Entomol. Fr. 35:440-442.

González-Hernández, H., M. W. Johnson, and N. J. Reimer. 1999a. Impact of Pheidole megacephala (F.) (Hymenoptera: Formicidae) on the biological control of Dysmicoccus brevipes (Cockerell) (Homoptera: Pseudococcidae). Biol. Control 15 (2): 145-152.

González-Hernández, H., N. J. Reimer, and M. W. Johnson. 1999b. Survey of the natural enemies of Dysmicoccus mealybugs on pineapple in Hawaii. BioControl (Dordr.) 44:47-58.

Green, O. R. 1992. New Zealand ants (Hymenoptera: Formicidae): Distribution and 
effects. Pages 67-72 in Proc., 41st Annu. Conf. N. Z. Entomol. Soc.

Greenslade, P. J. M. 1971. Interspecific competition and frequency changes among ants in Solomon Islands coconut plantations. J. Appl. Ecol. 8:323-352.

Heer, O. 1852. Über die Haus-Ameise Madeiras. Naturforsch. Gesel. 54:1-24.

Heraty, J. M. 1994. Classification and evolution of the Oraseminae in the Old World, with revisions of two closely related genera of Eucharitinae (Hymenoptera: Eucharitidae). Life Sci. Contrib. ROM 157:1-174.

Heterick, B. 1997. The interaction between the coastal brown ant, Pheidole megacephala (Fabricius) and other invertebrate fauna of Mt Coot-tha (Brisbane, Australia). Aust. J. Ecol. 22:218-221.

Heterick, B. E., J. Casella, and J. D. Majer. 2000. Influence of Argentine and coastal brown ant (Hymenoptera: Formicidae) invasions on ant communities in Perth gardens, Western Australia. Urban Ecosyst. 4:277-292.

Hinckley, A. D. 1969. Ecology of the terrestrial arthropods on the Tokelau Atolls. Atoll Res. Bull. 124:1-18.

Hoffmann, B. D. 1998. The big-headed ant Pheidole megacephala: A new threat to monsoonal northwestern Australia. Pac. Conserv. Biol. 4:250-255.

. 2004. Pheidole megacephala. Global Invasive Species Database. http://www.issg .org/database/species/distribution_detail .asp? $\mathrm{si}=132 \& \mathrm{di}=23152 \&$ sts $=$.

Hoffmann, B. D., A. N. Andersen, and G. J. E. Hill. 1999. Impact of an introduced ant on native rain forest invertebrates: Pheidole megacephala in monsoonal Australia. Oecologia (Berl.) 120:595-604.

Hoffmann, B. D., and S. O'Connor. 2004. Eradication of two exotic ants from $\mathrm{Ka}$ kadu National Park. Ecol. Manage. Restor. 5:98-105.

Hölldobler, B., and E. O. Wilson. 1990. The ants. Harvard University Press, Cambridge, Massachusetts.

Howarth, F. G. 1985. Impacts of alien land arthropods and mollusks on native plants and animals in Hawaii. Pages 149-179 in C. P. Stone and J. M. Scott, eds. Hawai'i's terrestrial ecosystems: Preservation and management. University of Hawai'i Press, Honolulu.

Huddleston, E. W., and S. S. Fluker. 1968. Distribution of ant species in Hawaii. Proc. Hawaii. Entomol. Soc. 20:45-69.

Illingworth, J. F. 1927. Predominance of Pheidole megacephala (Fab.) (Hymenoptera). Proc. Hawaii. Entomol. Soc. 6:389390.

Instituto Hórus. 2006. Espécies exóticas invasoras: Fichas técnicas. www.institutohorus .org.br/trabalhosa_fichas.htm.

Jahn, G. C., and J. W. Beardsley. 1994. Bigheaded ants, Pheidole megacephala: Interference with the biological control of gray pineapple mealybugs. Pages 199-205 in D. F. Williams, ed. Exotic ants: Biology, impact, and control of introduced species. Westview Press, Boulder, Colorado. 1996. Effects of Pheidole megacephala (Hymenoptera: Formicidae) on survival and dispersal of Dysmicoccus neobrevipes (Homoptera: Pseudococcidae). J. Econ. Entomol. 89:1124-1129.

Jones, V. P., D. M. Westcott, N. N. Finson, and R. K. Nishimoto. 2001. Relationship between community structure and southern green stink bug (Heteroptera: Pentatomidae) damage in macadamia nuts. Environ. Entomol. 30:1028-1035.

Jourdan, H. 1997. Are serpentine biota free from successful biological invasions? Southern New Caledonian ant community example. Pages 107-108 in T. Jaffré, R. D. Reeves, and T. Becquer, eds. Proc., 2nd Int. Conf. Serpentine Ecol. ORSTOM, Nouméa, New Caledonia.

Karawajew, W. 1935. Neue Ameisen aus dem Indo-Australischen Gebiet, nebst Revision einiger Formen. Treubia 15:57-118.

Kido, M. H., P. Ha, and R. A. Kinzie III. 1993. Insect introductions and diet changes in an endemic Hawaiian amphidromous goby, Awaous stamineus (Pisces: Gobiidae). Pac. Sci. 47:43-50.

Krauss, N. L. H. 1944. Notes on insects and other arthropods from the islands of Molokai and Maui, Hawaii. Proc. Hawaii. Entomol. Soc. 12:81-94.

Krushelnycky, P. D., L. L. Loope, and N. J. 
Reimer. 2005. The ecology, policy, and management of ants in Hawaii. Proc. Hawaii. Entomol. Soc. 37:1-25.

Lagnaoui, A., F. Cisnerros, J. Alcázar, and F. Morales. 2000. A sustainable pest management strategy for sweet potato weevil in Cuba: A success story. Pages 3-13 in C. Chien-The, ed. Control of weevils in sweet potato production. Proc. 12th Int. Symp. Int. Soc. Trop. Root Crops, Tsukuba, Japan.

LaPolla, J. S., D. Otte, and L. A. Spearman. 2000. Assessment of the effects of ants on Hawaiian crickets. J. Orthopt. Res. 9:139148.

Le Breton, J. 2003. Étude des interactions entre la fourmi Wasmannia auropunctata et la myrmécofaune. Comparaison d'une situation en zone d'introduction, la NouvelleCalédonie, et d'une situation en zone d'origine, la Guyane Française. Thesis, Université Toulouse III-Paul Sabatier, Toulouse, France.

Majer, J. D. 1985. Recolonization by ants of rehabilitated mineral sand mines on North Stradbroke Island, Queensland, with particular reference to seed removal. Aust. J. Ecol. 10:31-48.

Mann, W. M. 1925. Ants collected by the University of Iowa Fiji-New Zealand Expedition. Stud. Nat. Hist. Iowa Univ. 11 (4): 5-6.

Maza, N., A. Morales, O. Ortiz, P. Winters, J. Alcázar, and G. Scott. 2000. Impacto del manejo integrado del tetián del boniato (Cylas formicarius) en Cuba. Centro Internacional de la Papa (CIP), Lima, Perú.

Medeiros, A. C., L. L. Loope, and F. R. Cole. 1986. Distribution of ants and their effects on endemic biota of Haleakala and Hawaii Volcanoes National Park: A preliminary assessment. Pages 39-52 in Proc. 6th Conf. Nat. Sci., Hawai'i Volcanoes National Park, Hawai'i.

Nikitin, M. I. 1979. Geographical distribution of three species of small ants common in New South Wales. Aust. Entomol. Mag. 5:101-102.

Nishida, G. M. 2001. NOWRAMP 2000 Terrestrial arthropod report. U.S. Fish and Wildlife Service, Honolulu, Hawai'i.
Ogata, K., and S. Yamane. 1998. Pheidole megacephala (Fabricius). www.dna.affrc.go .jp/misc/ant.www/Taxo_E/F40604.html.

Onoyama, K. 1976. A preliminary study on the ant fauna of Okinawa-Ken, with taxonomic notes (Japan; Hymenoptera: Formicidae). Pages 121-141 in S. Ikehara, ed. Ecological studies of nature conservation of the Ryukyu Islands II. University of the Ryukyus, Naha, Okinawa.

Oswald, S. 1991. Application of the selective fire ant bait Amdro against the harmful brown house ant, Pheidole megacephala, for the improvement of the biological control of the coconut bug, Pseudotheraptus wayi, by the beneficial red weaver ant, Oecophylla longinoda. Z. Pflanzenkr. Pflansenschutz 98:358-363.

Perkins, R. C. L. 1913. Introduction. Fauna Hawaiiensis 1 (6): i-ccxxvii.

Perrault, G. H. 1988 (1987). Les fourmis de Tahiti. Bull. Soc. Zool. Fr. 112:429-446.

Reimer, N. J. 1994. Distribution and impact of alien ants in vulnerable Hawaiian ecosystems. Pages 11-22 in D. F. Williams, ed. Exotic ants: Biology, impact, and control of introduced species. Westview Press, Boulder, Colorado.

Reimer, N. J., and J. W. Beardsley Jr. 1990. Effectiveness of hydramethylnon and fenoxycarb for control of bigheaded ant (Hymenoptera: Formicidae), an ant associated with mealybug wilt of pineapple in Hawaii. J. Econ. Entomol. 83:74-80.

Reimer, N. J., J. W. Beardsley, and G. Jahn. 1990. Pest ants in the Hawaiian Islands. Pages 40-50 in R. K. Vander Meer, K. Jaffe, and A. Cedeno, eds. Applied myrmecology: A world perspective. Westview Press, Boulder, Colorado.

Reimer, N. J., M.-L. Cope, and G. Yasuda. 1993. Interference of Pheidole megacephala (Hymenoptera: Formicidae) with biological control of Coccus viridis (Homoptera: Coccidae) in coffee. Environ. Entomol. 22:483-488.

Reimer, N. J., and H. González-Hernández. 1993. Evidence for colony founding by haplometrosis in the bigheaded ant, Pheidole megacephala. Acta Hortic. 334:397405 . 
Reynolds, M., M. Vekasy, and E. Flint. 2005. Population status of the endangered Laysan Duck (Anas laysanensis). http://biology .usgs.gov/pierc/PLReynoldsLaysan1.htm.

Room, P. M. 1975. Diversity and organization of the ground foraging ant faunas of forest, grassland and tree crops in Papua New Guinea. Aust. J. Zool. 23:71-89.

Santschi, F. 1919. Cinq notes myrmécologiques. Bull. Soc. Vaudoise Sci. Nat. 52:325-350.

- 1928. Formicidae (Formis). Insects Samoa 5:41-58.

Schreiner, I. H. 1991. Sources of new insects established in Guam in the Post World War II period. Micronesica Suppl. 3:513.

Simmonds, F. J. 1958. The effect of lizards on the biological control of scale insects in Bermuda. Bull. Entomol. Res. 49:601612.

Simmonds, H. W. 1958. The housefly problem in Fiji and Samoa. South Pac. Comm. Q. Bull. 8 (2): 29-30, 47.

Smith, F. 1859. Catalogue of hymenopterous insects collected by Mr. A. R. Wallace at the islands of Aru and Key. J. Proc. Linn. Soc. Lond. Zool. 3:132-158.

. 1871. A catalogue of the aculeate Hymenoptera and Ichneumonidae of India and the Eastern Archipelago. With introductory remarks by A. R. Wallace. J. Linn. Soc. Lond. Zool. 11:285-348.

1879. Descriptions of new species of aculeate Hymenoptera collected by the Rev. Thos. Blackburn in the Sandwich Islands. J. Linn. Soc. Lond. Zool. 14:674685.

Sonobe, R. 1973. Ant fauna of the Sesoko Island, Okinawa. Sesoko Mar. Sci. Lab. Tech. Rep. 2:15-16.

Starr, F., K. Starr, and L. L. Loope. 2004. New arthropod records from Kaho'olawe. Bishop Mus. Occas. Pap. 79:5054.

Stechmann, D. H., W. Volkl, and P. Stary. 1996. Ant-attendance as a critical factor in the biological control of the banana aphid Pentalonia nigronervosa Coq. (Hom.: Aphididae) in Oceania. J. Appl. Entomol. 120:119-123.
Sugerman, B. B. 1972. Insects and other arthropods from Kwajalein Atoll (Marshall Islands). Proc. Hawaii. Entomol. Soc. 21:271-286.

Taniguchi, G., T. Thompson, and B. Sipes. 2005. Control of the big-headed ant, Pheidole megacephala (Hymenoptera: Formicidae), in pineapple cultivation using Amdro in bait stations. Sociobiology 45:1-7.

Taylor, R. W. 1961. Notes and new records of exotic ants introduced into New Zealand. N. Z. Entomol. 2 (6): 28-37. 1967. Entomological survey of the Cook Islands and Niue. 1. HymenopteraFormicidae. N. Z. J. Sci. 10:1092-1095. . 1971. The ants (Hymenoptera: Formicidae) of the Kermadec Islands. N. Z. Entomol. 5:81-82.

Terayama, M., S. Miyano, and T. Kurozumi. 1994. Ant fauna (Insecta: Hymenoptera: Formicidae) of the Northern Mariana Islands, Micronesia. Pages 231-236 in A. Asakura and T. Furuki, eds. Biological expedition to the Northern Mariana Islands, Micronesia. Nat. Hist. Res. Spec. Issue, No. 1. Nat. Hist. Mus. Inst., Chiba, Japan.

Timberlake, P. H. 1926. Hymenoptera. Pages 17-43 in E. H. Bryan Jr. and collaborators. Insects of Hawaii, Johnston Island and Wake Island. Bernice P. Bishop Mus. Bull. 31:1-94.

Tinzaara, W., C. S. Gold, M. Dicke, and A. Van Huis. 2005. Olfactory responses of banana weevil predators to volatiles from banana pseudostem tissue and synthetic pheromone. J. Chem. Ecol. 31:1537-1553. Torres, J. A., and R. R. Snelling. 1997. Biogeography of Puerto Rican ants: A nonequilibrium case? Biodivers. Conserv. 6:1103-1121.

Tothill, J. D., T. H. C. Taylor, and R. W. Paine. 1930. The coconut moth in Fiji. Imperial Bureau of Entomology, London.

Tryon, H. 1912. The naturalization of an exotic ant (Pheidole megacephala Fab.). Queensl. Nat. 1:224-229.

Vanderwoude, C., L. A. L. de Bruyn, and A. P. N. House. 2000. Response of an openforest ant community to invasion by the introduced ant, Pheidole megacephala. Aust. Ecol. 25:253-259. 
Wetterer, J. K. 1998. Nonindigenous ants associated with geothermal and human disturbance in Hawai'i Volcanoes National Park. Pac. Sci. 52:40-50.

- 2002. Ants of Tonga. Pac. Sci. $56: 125-135$.

. 2006a. Ants (Hymenoptera: Formicidae) of Niue, Polynesia. Pac. Sci. 60:413416.

-2006b. Quotation error, citation copying, and ant extinctions in Madeira. Scientometrics 67:351-372.

Wetterer, J. K., P. C. Banko, L. P. Laniawe, J. W. Slotterback, and G. J. Brenner. 1998. Nonindigenous ants at high elevations on Mauna Kea, Hawai'i. Pac. Sci. $52: 228-236$

Wetterer, J. K., X. Espadaler, A. L. Wetterer, D. Aguin-Pombo, and A. M. FranquinhoAguiar. 2006. Long-term impact of exotic ants on the native ants of Madeira. Ecol. Entomol. 31:358-368.

Wetterer, J. K., and D. L. Vargo. 2003. Ants (Hymenoptera: Formicidae) of Samoa. Pac. Sci. 57:409-419.

Wetterer, J. K., and A. L. Wetterer. 2004. Ants (Hymenoptera: Formicidae) of Bermuda. Fla. Entomol. 87:212-221.

Wheeler, W. M. 1908. Ants from Moorea, Society Islands. Bull. Am. Mus. Nat. Hist. 24:165-167.

1909. Ants of Formosa and the Philippines. Bull. Am. Mus. Nat. Hist. 26:333345.

_ 1910. Ants: Their structure, development and behavior. Columbia University Press, New York.

- 1922. The ants collected by the American Museum Congo Expedition. Bull. Am. Mus. Nat. Hist. 45:39-269.

- 1924. Ants of Krakatau and other islands in the Sunda Strait. Treubia 5:239258.

. 1927. Chinese ants collected by Professor S. F. Light and Professor N. Gist Gee. Am. Mus. Novit. 255:1-12.

- 1929. Ants collected by Professor F. Silvestri in Formosa, the Malay Peninsula and the Philippines. Boll. Lab. Zool. Gen. Agr. Reale Scuola Sup. d'Agr. Portici 24:27-64.
- 1932a. Ants of the Marquesas Islands. Bernice P. Bishop Mus. Bull. 98:155-163.

. 1932b. Ants from the Society Islands. Bernice P. Bishop Mus. Bull. 113:13-19.

- 1933. A new species of Ponera and other records of ants from the Marquesas Islands. Bernice P. Bishop Mus. Bull. 114:141-144. 1934. Revised list of Hawaiian ants. Occas. Pap. Bernice Pauahi Bishop Mus. 10:1-21. . 1935. Check list of the ants of Oceania. Occas. Pap. Bernice Pauahi Bishop Mus. 11 (11): 1-56.

. 1936. Ants from the Society, Austral, Tuamotu and Mangareva Islands. Occas. Pap. Bernice Pauahi Bishop Mus. 12 (18): 3-17.

Wiles, G. J., I. H. Schreiner, D. Nafus, and J. C. Manglona. 1996. The status, biology, and conservation of Serianthes nelsonii $(\mathrm{Fa}-$ baceae), an endangered Micronesian tree. Biol. Conserv. 76:229-239.

Wilson, E. O. 1984. Tropical social parasites in the ant genus Pheidole, with an analysis of the anatomical parasitic syndrome (Hymenoptera: Formicidae). Insectes Soc. 31:316-334.

Wilson, E. O., and G. L. Hunt. 1967. Ant fauna of Futuna and Wallis Islands, stepping stones to Polynesia. Pac. Insects 9:563-584.

Wilson, E. O., and R. W. Taylor. 1967. Ants of Polynesia. Pac. Insects Monogr. 14:1109.

Wingate, D. B. 1965. Terrestrial herpetofauna of Bermuda. Herpetologica 21:202218.

World Resources Institute. 2000. World Resources 2000-2001: People and ecosystems: The fraying web of life. World Resources Institute, Washington, D.C.

Yamauchi, K., and K. Ogata. 1995. Social structure and reproductive systems of tramp versus endemic ants (Hymenoptera: Formicidae) of the Ryukyu Islands. Pac. Sci. 49:55-68.

Zerhusen, D., and M. Rashid. 1992. Control of the bigheaded ant Pheidole megacephala Mayr (Hym., Formicidae) with fire ant 
bait 'AMDRO' and its secondary effect on the population of the African weaver ant Oecophylla longinoda Latreille (Hym., Formicidae). J. Appl. Entomol. 113:258264.

Zhou, S., and Z. Zheng. 1999. Taxonomic study of the ant genus Pheidole Westwood from Guangxi, with descriptions of three new species (Hymenoptera: Formicidae). Acta Zootaxonomica Sin. 24:83-88.

Zimmerman, E. C. 1948. Insects of Hawaii. Vol. 1. Introduction. University of Hawaici Press, Honolulu.

. 1970. Adaptive radiation in Hawaii with special reference to insects. Biotropica $2: 32-38$. 